\title{
Tillsyn och annan eftervård efter kort frihetsstraff
}

\author{
Av skyddskonsulent BöRJE NYBLOM.
}

Ove är en 20-åring, som är född inom äktenskapet. Då han var 7 år, skildes föräldrarna. Fadern, som var svårt alhoholiserad och straffad upprepade gånger, misshandlade både hustrun och barnen och körde vid flera tillfällen ut dem från hemmet. Efter skilsmässan bodde Ove hos modern, som efter ett par år gifte om sig. Hemförhållandena blev därefter goda. De skador Ove ådrog sig under sina tidigaste barnaår synes emellertid ha blivit så fixerade hos honom, att den nya och bättre miljön icke haft möjligheter att läka dessa. Då Ove vid 18 års ålder blev rättspsykiatriskt undersökt, skrev nämligen läkaren, att Ove vars intellektuella utrustning låg i underkant av det normala, företedde bristande utveckling i känslo- och viljehänseende. Orsaken härtill ansågs vara dels konstitutionellt betingad, dels orsakad av neurotiserande upplevelser under uppväxtåren, varigenom han fixerats till vissa lustbemängda föreställningar och komplex, som verkat direkt hämmande på hans naturliga utveckling, på känsloengagemang, karaktär och viljeanspänning, på livsbejakning och förmåga till kontakter och anpassning i livet. Hans brottslighet ansåg läkaren fick ses som en följd härav och hans inre disharmoni och missnöje med sig själv och omvärlden. Oves kriminalisering började, då han var 17 år. Han fick då en villkorlig dom för försök till stöld. Redan efter 2 månader återföll han i brottslighet och dömdes med förverkande av den villkorliga domen till straffarbete 5 månader. Efter avtjänat straff frigavs han under våren 1959, varefter han synes ha skött sig omkring ett halvt år. Han bodde under denna tid hos modern och styvfadern och uppgives ha haft tillfälliga anställningar. För brottslighet, som började under hösten 1959, dömdes han i maj månad 1960 till straffarbete 1 år. Straffavtjänandet gick ingalunda friktionsfritt, då han gjorde sig skyldig till upprepade rymningar, thinnersniffning, arbetsvägran $\mathrm{m}$. $\mathrm{m}$. På grund av sitt dåliga uppförande beviljades han inte fakultativ villkorlig frigivning utan blev i juni månad 1961 obligatoriskt villkorligt frigiven och ställdes under tillsyn. Han fick bostad i föräldrahemmet och arbete vid ett vägentreprenadföretag. Redan efter 18 dagar gjorde han sig emellertid skyldig till en inbrottsstöld och dömdes till straffarbete 4 månader. Han skall $\mathrm{i}$ dagarna frigivas och kommer åter att ställas under tillsyn, då hans sammanlagda strafftid till följd av förverkad villkorlig frigivning uppgår till 6 månader. Han får nu inte komma tillbaka till hemmet, där man tröttnat på honom 
och inte har någon hand med honom. Han är håglös och ointresserad för sin framtid och vill inför frigivningen inte ha hjälp i något avseende. Troligen är han rädd för frigivningen. På den anstalt, där han avtjänar straffet, finnes närmare 150 andra intagna. Det är uteslutet, att man där skall hinna ägna denne stackare den tid, som det skulle kräva att komma till rätta med hans problem. Ingen kan väl tro, att denne yngling på egen hand skall kunna reda upp sina förhållanden efter frigivningen.

Genom den summariska skildringen av fallet Ove, som tyvärr icke är ett sällsynt eller extremt fall, har jag velat belysa, hur bristfälliga våra resurser inom kriminalvården såväl pă anstalt som i frihet trots allt är.

Jag har tagit Ove, som avtjänar ett sexmånadersstraff, som ett exempel på en korttidare. Därmed har jag fastställt, att jag med kort frihetsstraff avser straff upp till 6 månader. Av korttidsstraffade enligt denna beräkningsgrund fanns i Sverige den 1 december 1961 inte mindre än 1.644 straff- och fängelsefångar, medan hela antalet straff- och fängelsefångar vid samma tidpunkt uppgick till 3.467. Då det är en vanlig uppfattning, att korttidarna till övervägande del består av personer, dömda för rattfylleri eller andra trafikbrott och för vilka eftervårdsåtgärder sällan är påkallade, vill jag nämna att dessas antal var 426 . Kvar står följaktligen 1.018 intagna, som den 1 december 1961 undergick straffarbete eller fängelse för andra brott än trafikbrott. Vidare bör jag nämna, att av dessa 1.018 intagna kunde 403 komma att frigivas med tillsyn genom antingen obligatorisk eller fakultativ villkorlig frigivning. Det är följaktligen över 600, som kommer att frigivas utan någon form av tillsyn.

Frågan är då, vad som göres och vad som ytterligare kan göras för att förbereda korttidarnas frigivning. Eftervården bör planeras redan vid straffets början och den bör följas med uppmärksamhet under hela strafftiden. En korttidares frigivningsproblem är säkerligen ofta av samma svårighetsgrad som långtidarens. För korttidaren är det därför särskilt angeläget att anstaltstiden tages väl till vara. Tyvärr gör vi oss nog skyldiga till dålig planering och slentriantänkande vad beträffar förberedelserna av korttidarnas frigivning. Då den intagne börjar straffavtjänandet, utarbetas en behandlingsjournal beträffande honom och ett kollegium fastställer en behandlingsplan. Härvid diskuteras även den intagnes frigivningssituation. Korttidarna uppger ofta, att de inga frigivningsproblem har; bostadsförhållandena är ordnade och efter avtjänat straff får de återvända till den senaste arbetsplatsen, deras enda bekymmer är, att de sitter inne, efter frigivningen ordnar sig allt. Vi tar ofta dessa uppgifter för gott. Våra personella resurser är begränsade och vi är tacksamma för att det är ett antal intagna, vars eftervårdsproblem vi inte behöver 
använda vår dyrbara tid på. Enligt min uppfattning borde vi inte underlåta att på lämpligt sätt kontrollera varje intagens uppgifter i dessa avseenden. Om en sådan kontroll vidtages, skall det visa sig, att alltför många överskattar sina möjligheter att ordna för sig vid frigivningen. Sedan det konstaterats att den intagne är i behov av hjälp, exempelvis med arbetsanskaffning, tror jag, att man genom att visa honom intresse för hans speciella problem kan få honom att aktivt medverka i förberedelserna för frigivningen och därigenom kan också den negativa inställning mot samhällets organ, som man så ofta möter hos dessa människor, elimineras. Kan vi få den intagne samarbetsvillig vet vi alla, att det finns en mångfald små och stora problem, som möter den frigivne och som kan lösas redan under anstaltstiden. Jag behöver som exempel endast nämna anskaffandet av arbetsbetyg, hopsamlandet av spridda tillhörigheter och ordnandet av uppskov och anstånd med olika betalningsskyldigheter. Exemplifieringen rör sig om relativt triviala angelägenheter, som, olösta vid en frigivning, kan torna upp sig till problem.

Jag vill också hålla före, att det i Sverige i allt större utsträckning tillämpade systemet att redan under straffavtjänandet förordna tillsynsmannen, kan få stor betydelse för eftervården. Vad beträffar de korttidare, som skall frigivas utan tillsyn, skulle jag vilja föreslå, att vi för dem i ökad omfattning använder oss av någon form av fängelsebesökare.

Vi vet, att ett mycket stort antal brott begås av människor under alkoholpåverkan. Även om meningarna bryts vad det gäller orsakssammanhangen mellan brottslighet och alkoholbruk, så finnes det alla skäl att uppmärksamma de intagnas alkoholproblem. En klok och fattbar upplysningsverksamhet bland de intagna om alkoholens skadeverkningar tror jag skulle vara betydelsefull. Jag vill också hålla för troligt att en orientering om de möjligheter och resurser, som står till nykterhetsvårdens förfogande, skall göra de intagna mer benägna att både vidgå sina alkoholproblem och söka den hjälp, som kan givas. Har vi kommit så långt bör det finnas möjligheter att få en kanske inte så liten grupp intagna att före frigivningen påbörja någon form av antialkoholbehandling. Det borde också vara självklart, att de intagna, som före straffavtjänandet var föremål för nykterhetsnämndens behandling, skall under anstaltstiden uppsökas eller på annat sätt följas av nykterhetsnämnden. Att som nu ofta sker, nykterhetsnämnden avskriver ärendet, då vederbörande omhändertages av fångvården, kan inte vara rationellt. Ett nära och intimt samarbete mellan de båda vårdorganen bör i stället uppehållas.

Vidare bör i ökad omfattning arbetsförmedlingarnas tjänstemän för att förbereda de intagnas arbetsplacering vid frigivningen 
beredas möjlighet att besöka inte endast några av de större, centralt belägna anstalterna utan även kunna utsträcka sin verksamhet till personliga besök vid varje fångvårdsanstalt. Resultaten av ett intimt samarbete mellan anstaltspersonal, den intagne och arbetsförmedlingstjänstemannen har visat sig mycket goda, varför en intensifiering av detta samarbete måste vara av största värde.

Jag vill vidare framhålla betydelsen av den gruppterapi, som under några år förekommit inom den svenska fångvården. Denna verksamhet bör utvidgas och intensifieras och den bör fortgå även efter frigivningen. Det får anses som orimligt, att de intagna vare sig de avtjänar längre eller kortare frihetsstraff under denna tid icke regelmässigt blir föremål för en terapi i någon form. Jag vill påstå, att så länge vi inte på allvar med alla till buds stående medel söker komma till rätta med de intagnas inre spänningar och psykiska särdrag måste fångvårdens resultat bli blygsamma och även en väl utrustad frivårds möjligheter begränsade.

Med en efter de riktlinjer, som jag här skisserat, under anstaltstiden planerad eftervård blir den egentliga eftervården, frivården, ingen ny vårdform utan endast en fortsatt eftervård. Det råder emellertid ingen tvekan om att vi ofta tänker på anstaltsvården och frivården som två från varandra skilda vårdområden. När straffet är avtjänat avbrytes anstaltens eftervård. Frivården betraktas som en ny vårdform utan större samhörighet med anstaltsvården. Naturligtvis äger ett visst samråd rum mellan de båda vårdområdena och även om under senare år ett ganska intimt samarbete upprättats, så går det icke att dölja att det finnes en klyfta mellan de båda vårdområdena. För att åstadkomma ett bättre resultat av den samlade eftervården är det nödvändigt att denna klyfta överbygges och enligt min mening kan detta bäst ske genom att frivărdens personal får ansvaret även för den eftervård, som påbörjas under anstaltstiden. I detta förslag, som för övrigt framförts av 1956 års eftervårdsutredning ligger ingen misstro mot anstaltspersonalens kompetens att sköta eftervårdsfrågorna utan jag finner det endast naturligt att dessa frågor skall om möjligt lösas av ett enda organ. Skyddskonsulenten, skyddsassistenten eller tjänstemannen vid skyddsföreningen bör regelmässigt medverka vid behandlingsplanens fastställande och redan då uppmärksamma frigivningsproblemen. Sedan bör dessa tjänstemän — givetvis med biträde av anstaltspersonalen - försöka komma till en lösning av dessa problem, varigenom frigviningen och eftervården ständigt blir aktuell, såväl för tjänstemannen som för de intagna. För dessa måste ett sådant förfarande skapa ett visst mått av trygghet och frigivningen behöver inte framstå som ett steg ut i det okända. Den frigivne vet vart han skall vända sig med sina problem och känner redan dem han 
möter i frivården och dessa är väl orienterade om hans problem.

Genomförandet av en eftervård, som planeras och följes redan från frihetsstraffets början kräver stora personella resurser. Den kräver också god utbildning och gott handlag av sina utövare. Den utbyggnad av skyddskonsulentorganisationen, som i Sverige föreslagits skall äga rum under de närmast följande tre åren, torde ge möjligheter till en effektivare eftervård. För att ytterligare förstärka eftervårdens resurser kommer statsmakterna genom att lämna skyddsvärnen i Stockholm och Göteborg ekonomiskt stöd att inlemma dessa föreningars verksamhet $i$ den samlade eftervården. För eftervårdens personella resurser synes för kommande år följaktligen bli tämligen väl sörjt. Eftervårdens tjänstemän måste för att lösa eftervårdsproblemen lita även till andra vårdområdens resurser och möjligheter. Jag tänker därvid främst på sådana vårdområden och organ som nykterhetsvården och arbetsförmedlingen med dess arbetsvård. Med bristfälliga resurser på dessa områden kan det tänkas att nykterhetsvården kan skjuta ansvaret ifrån sig för en villkorligt frigiven, som missbrukar alkohol, under förmenande att den frigivne på grund av misskötsamhet bör återintagas på fångvårdsanstalt. Arbetsvården kan i trängda lägen med minskad tillgång på arbetstillfällen tänkas ställa de straffade i efterhand. Det är lätt att konstatera ett fysiskt handicap, som klassificerar den sökande som partiellt arbetsför, medan det kan vara betydligt svårare att få hållpunkter för det psykiska handicap, som kanske leder till en asocial livsföring.

Vad gäller ansvarsfördelningen i eftervården mellan stat, representerad av fångvården, och kommun, representerad exempelvis av nykterhetsvården, kan meningarna vara delade. Att fångvården skulle svara för den nykterhetsvård eller den arbetsförmedlande versamhet, som erfordras för dess klientel, vore orimligt och liktydigt med en tillbakagång i utvecklingen. Däremot torde det kunna diskuteras, huruvida icke nykterhetsvård och arbetsförmedling borde avdela tjänstemän, som helt ägnade sig åt fångvårdens klientel. Förslag i detta avseende vad gäller arbetsförmedlingens insatser har framförts av 1956 års eftervårdsutredning.

Vad ytterligare gäller ansvarsfördelningen i eftervården har jag deklarerat, att enligt min uppfattning bör ansvaret för hela eftervården, den som påbörjas under anstaltstiden och den som följer efter frigivningen, åvila skyddskonsulentorganen. Min uppfattning i detta avseende delas i varje fall icke av alla fångvårdsmän. Sålunda anser bland andra personal, som handhar vården av de förvarade, att de goda relationer, som icke sällan uppstår mellan intagna och viss personal på en förvaringsanstalt, icke 
bör brytas vid en utskrivning utan fortgå i form av eftervård och tillsyn.

Slutligen, och som kanske viktigaste fråga i den kommande diskussionen, kvarstår problemet eftervården för de i snävare bemärkelse från kort frihetsstraff frigivna. Jag avser därvid de intagna, som frigivas utan tillsyn. Även om jag tidigare framhållit, att jag tror att dessa korttidare med en effektivare förberedelse av eftervården på anstaltsplanet, skall frivilligt använda sig av eftervårdens resurser och möjligheter till stöd och hjälp, innebär icke detta någon garanti för att inte stora grupper av dessa korttidare söker på egen hand och efter bristfällig förmåga lösa sina problem. I Sverige vet vi i dag mycket litet om hur dessa korttidares förhållanden ter sig efter frigivningen. Vissa skyddsföreningar bedriver stödjande verksamhet även för korttidare men denna verksamhets omfattning har vi inte säkra uppgifter om. Även skyddskonsulenterna är skyldiga att befatta sig med andra än villkorligt dömda och villkorligt frigivna men deras befattning med korttidare utan tillsyn torde vara ringa. Vi kan emellertid genom studier av personakter över fångvårdsklientelet konstatera, att ett mycket stort antal korttidare gång på gång dömes till nya korttidsstraff och att deras möjligheter till återanpassning i samhällslivet blir allt mindre. Att på sätt som nu sker lämna en relativt stor grupp frigivna åt sitt öde är både meningslöst och inhumant. Eftervården för de korttidare, som frigives utan tillsyn är en allvarlig fråga, som måste lösas. Som en utväg att lösa denna fråga ser jag det förslag om utvidgad användning av fakultativ villkorlig frigivning som i Sverige diskuteras, en fakultativ villkorlig frigivning, som är tillämplig efter alla frihetsstraff. Själv har jag ställt mig tveksam till en reform, som måste kräva så väsentligt utökade resurser både av det beslutande organet och av tillsynsorganisationen. En annan utväg att lösa eftervårdsproblemen som för mig inte framstår såsom helt orealistisk, skulle kunna tänkas vara att i lag fastslå att efter varje avtjänat frihetsstraff skall följa en övervakning tillsyn av viss tidslängd. Jag är icke övertygad om effektiviteten hos den eftervård, som påtvingas en villkorlig frigiven under det straffhot, som ett förverkande av den villkorligt medgivna friheten innebär. Som jag tidigare framhållit tror jag på en aktiv och positiv medverkan från de intagna och frigivna själva i eftervårdsproblemens lösande om vi med förbättrade resurser gives möjligheter att åstadkomma en vård, som syftar till att komma till rätta med de intagnas psykiska särdrag och defekter. 